\title{
Sinonasal Chondromyxoid Fibroma: Case Report and Literature Review
}

\author{
Nadeem El-Kouri ${ }^{1}$, Alhasan Elghouche ${ }^{2}$, Shaoxiong Chen ${ }^{3}$, Taha Shipchandler ${ }^{4}$, Jonathan Ting ${ }^{4}$ \\ 1. Department of Otolaryngology - Head and Neck Surgery, Loyola University Chicago Stritch School of Medicine, \\ Maywood, USA 2. Department of Medical Education and Simulation, Indiana University School of Medicine, \\ Indianapolis, USA 3. Department of Pathology and Laboratory Medicine, Indiana University School of Medicine, \\ Indianapolis, USA 4. Department of Otolaryngology - Head and Neck Surgery, Indiana University School of Medicine, \\ Indianapolis, USA
}

Corresponding author: Alhasan Elghouche, aelghouc@iupui.edu

\begin{abstract}
Chondromyxoid fibroma (CMF) is a rare, benign neoplasm of the chondroid, myxoid, and fibrous tissue. It characteristically affects the lower extremity long bones, although it may rarely arise within the craniofacial skeleton. We report the diagnosis and management of a 31-year-old male with a large, incidentally discovered CMF originating from the sphenoid sinus. A subsequent review of the literature reveals the need to differentiate from more aggressive neoplasms, such as chondrosarcoma and chondroma, which share radiographic features. A histopathologic examination is crucial for proper diagnosis and treatment. We discuss clinical sequelae, highlight the importance of a thorough pre-operative evaluation, and summarize previously suggested treatment paradigms.
\end{abstract}

Categories: Otolaryngology

Keywords: chondromyxoid fibroma, cmf, sinonasal tumors, review of chondromyxoid fibroma

\section{Introduction And Background}

Originally described in 1948 by Jaffe and Lichtenstein, the chondromyxoid fibroma (CMF) is a neoplasm of cartilaginous origin [1] accounting for $<0.5 \%$ of all bone tumors [2-4], with a slight male predominance [5]. Although more commonly found in the metaphysis of long bones, between 1-5\% of CMF cases are reported to occur in the head and neck [5-6].

Cases have been reported in all the paranasal sinuses. Given its benign nature, patients may not present until secondary symptoms manifest. These symptoms depend on tumor size and location but may include diplopia, facial pain, exophthalmos, neuralgia, dysarthria, epistaxis, nasal congestion, headache, bony swelling, or persistent chronic rhinosinusitis [7]. Given the rarity of CMF, it is crucial to consider more aggressive neoplasms, including chondrosarcoma and chordoma. We report the diagnosis and management

Received 08/27/2019

Review began 09/06/2019 Review ended 10/03/2019 Published 10/05/2019

\section{() Copyright 2019}

El-Kouri et al. This is an open access article distributed under the terms of the Creative Commons Attribution License CC-BY 3.0., which permits unrestricted use, distribution, and reproduction in any medium, provided the original author and source are credited. of a patient with CMF originating from the sphenoid sinus and review the available literature describing its presence within the head and neck with a focus on the paranasal sinuses.

\section{Case presentation}

A previously healthy 31-year-old male presented to the Otolaryngology - Head \& Neck Surgery clinic, with right-sided nasal airway obstruction. Physical examination, including nasal endoscopy, revealed a large mass within the right nasal passage. He had no associated symptoms such as visual complaints, paresthesia, and facial pain. A biopsy was performed in the operating room, with the histopathologic evaluation revealing a lobular growth pattern with stellate or spindle-shaped cells in a chondroid background (Figure 1). Well-developed hyaline cartilage was not present. The pathology report stated the morphological features were consistent with CMF.
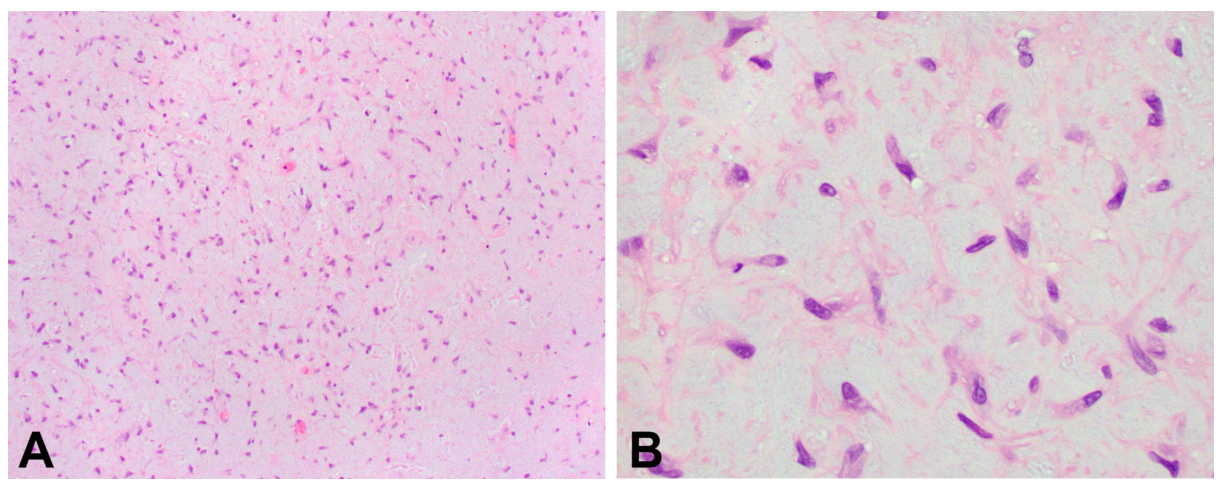


\section{Cureus}

FIGURE 1: Histopathologic images. A (Left). Microscopic examination reveals stellate or spindle-shaped cells with abundant chondromyxoid matrix (100x). B (Right) Lesional cells with eosinophilic cytoplasm and mildly pleomorphic nuclei containing finely dispersed or homogeneous dark chromatin (400x).

Prior to definitive resection, preoperative computed tomography (CT) and magnetic resonance imaging (MRI) imaging were completed for anatomic mapping and surgical planning. CT revealed a homogeneously enhancing mass with scattered coarse central calcifications. There was extensive bony remodeling and displacement without aggressive osseous erosion. Although centered within the right nasal cavity, the lesion was found to erode through the nasal septum into the left nasal cavity (Figure $2 A$ ). The mass extended to the level of the right nasolacrimal canal anteriorly and to the level of the right choana and nasopharynx inferiorly. Laterally, the mass deformed the medial wall of the left maxillary sinus and obstructed the maxillary sinus ostium with associated sinus opacification. Posterior involvement was noted within the right sphenoid sinus and left posterior ethmoid sinuses. There was no obvious intracranial or intraorbital extension. MRI with and without contrast supported the CT findings and demonstrated cystic components (Figure $2 B$ ) with relative T2 hypointensity concerning for high cellularity or a high nuclear-to-cytoplasmic ratio. No perineural spread or adenopathy was noted.

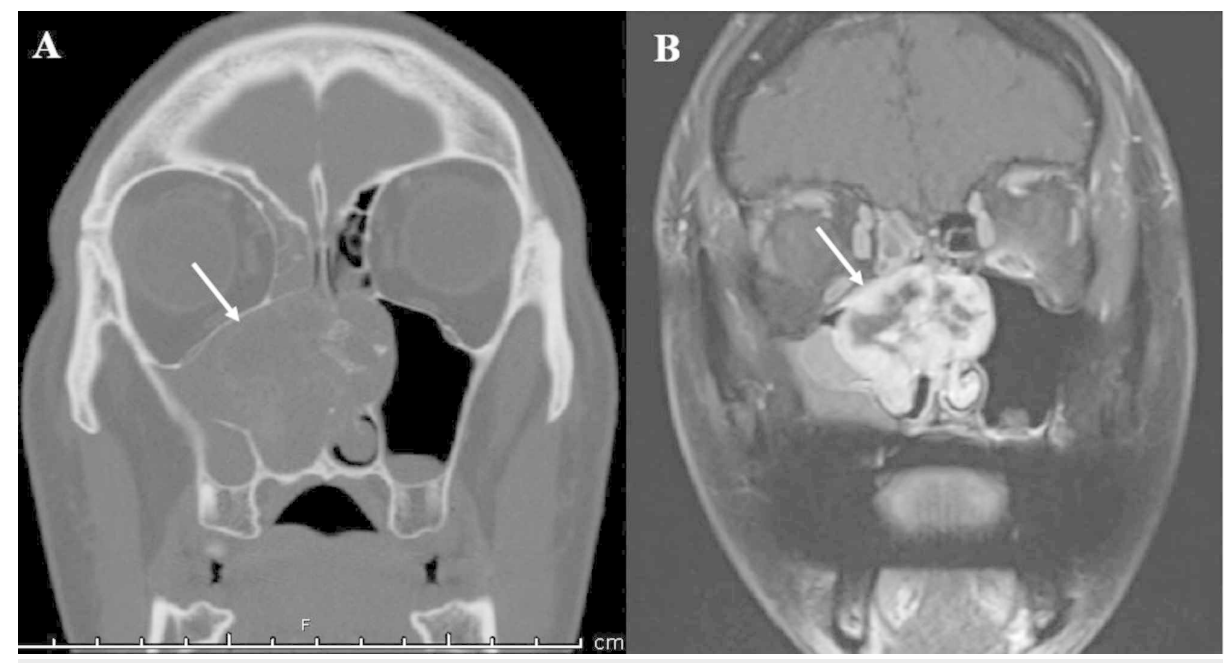

FIGURE 2: CT and MR imaging. (A) Contrast-enhanced CT scan demonstrating an expansile mass centered within the right nasal cavity with extension into the left nasal passage (white arrow), with scattered calcifications. (B) The same mass (white arrow) observed on contrastenhanced T1-weighted MRI with heterogeneous uptake.

One month later, the patient underwent endoscopic resection under general anesthesia. Intraoperatively, the tumor was noted to attach to the planum sphenoidale without dural involvement. The tumor was found to extend from the sphenoid with erosion through the posterior septum to involve the left posterior ethmoid cavity (Figure 3). 


\section{Cureus}

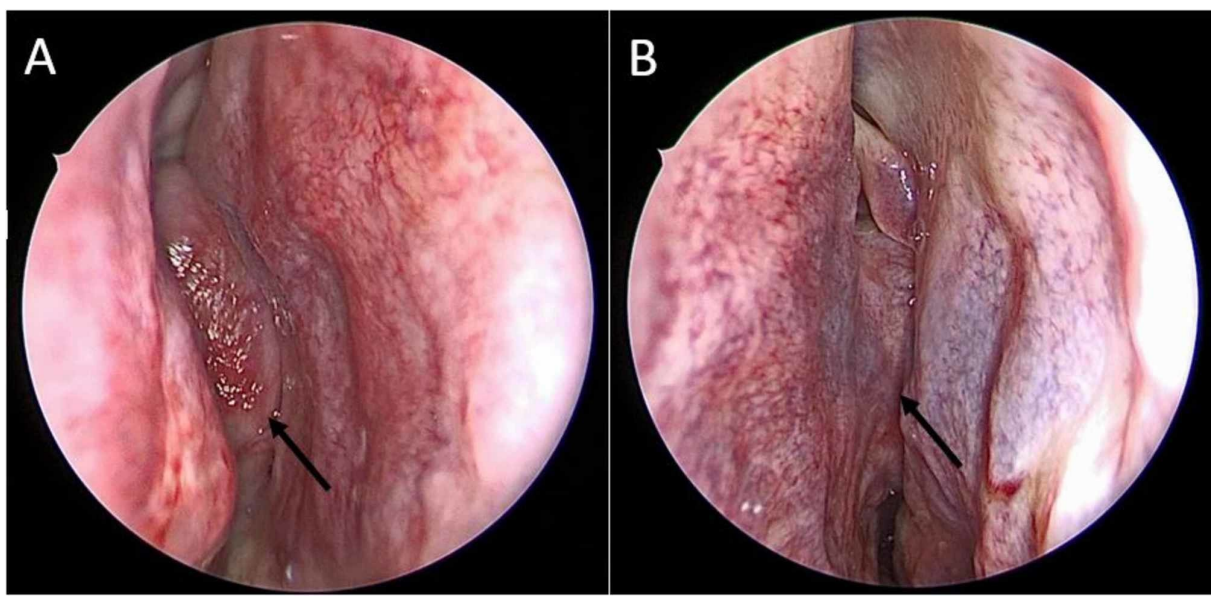

FIGURE 3: Intraoperative photos. (A) Endoscopic view demonstrating a mass (black arrow) within the right nasal cavity at the level of the middle meatus. (B) Endoscopic view demonstrating extension of the mass (black arrow) across the nasal septum to involve the left nasal cavity.

In addition to complete tumor resection, bilateral maxillary antrostomies and sphenoethmoidectomies were performed as well as a posterior septectomy. The left middle turbinate was also resected due to tumor involvement. There was no intraoperative cerebrospinal (CSF) fluid leak.

The postoperative course was uneventful and a follow-up CT scan was obtained two weeks later without evidence of residual disease, as seen in Figure 4.

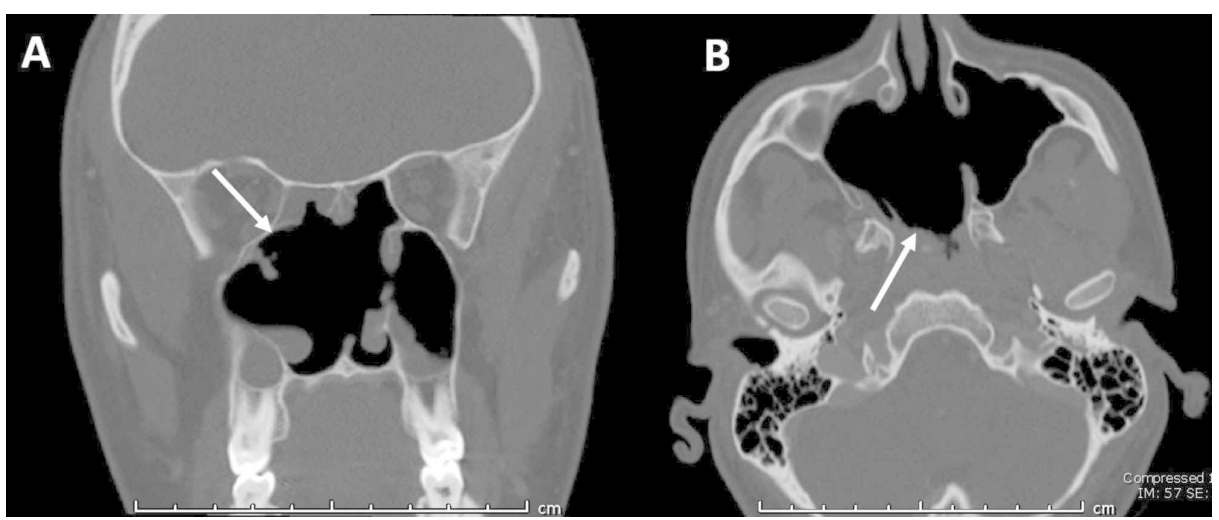

FIGURE 4: Postoperative CT images. (A) Coronal and (B) axial images showing complete tumor resection (arrows), bilateral maxillary antrostomies and sphenoethmoidectomies and posterior septectomy.

\section{Review}

CMF is a slow-growing and rare neoplasm consisting of chondroid, myxoid, and fibrous tissue. CMF accounts for less than $0.5 \%$ of all bone tumors [2-4], with a slight male predominance [5]. Although it is most commonly found in the metaphysis of long bones, craniofacial involvement has been reported and comprised $5.4 \%$ of the $278 \mathrm{CMF}$ cases surveyed by Wu et al. [5]. This benign, albeit locally aggressive tumor is most commonly found in patients in the second or third decades of life [8]. The rare occurrence rate of CMF makes it a challenging disease to study directly and the presentation of a single case is a relative limitation of the present study. An examination of the literature reveals a number of studies with reported areas of involvement of much of the skeleton. Within the head and neck, cases have been identified in the paranasal sinuses, mastoid process, sella turcica, and clivus [9]. Additional details, including patient demographic data, location, treatment, and follow-up of all reported cases of paranasal CMF can be found in Table 1 . 


\begin{tabular}{|c|c|c|c|c|c|c|}
\hline Author & $\begin{array}{l}\text { Age } \\
\text { y, } \\
\text { mo, } \\
\text { or d/ } \\
\text { Sex }\end{array}$ & Location & Treatment & Follow-up & Clinical presentation & $\begin{array}{l}\text { Duration } \\
\text { of } \\
\text { symptoms }\end{array}$ \\
\hline $\begin{array}{l}\text { Keel et al. } \\
{[10]}\end{array}$ & $\begin{array}{l}65 \\
y / F\end{array}$ & $\begin{array}{l}\text { Clivus with extension } \\
\text { to sphenoid and } \\
\text { ethmoid sinuses }\end{array}$ & Curettage and radiation & $\begin{array}{l}\text { Local } \\
\text { recurrence } \\
\text { after } 6 \mathrm{mo} ; \\
\text { after } \\
\text { radiation, } 20 \\
\text { mo DF }\end{array}$ & \multirow[t]{2}{*}{$\begin{array}{l}2 / 3 \text { patients in this series } \\
\text { presented with headache } \\
\text { while other presented } \\
\text { with nasal obstruction }\end{array}$} & NA \\
\hline $\begin{array}{l}\text { Keel et al. } \\
{[10]}\end{array}$ & $\begin{array}{l}66 \\
y / F\end{array}$ & $\begin{array}{l}\text { Clivus with extension } \\
\text { to sphenoid and } \\
\text { ethmoid sinuses }\end{array}$ & Curettage & 26 mo DF & & NA \\
\hline $\begin{array}{l}\text { Isenberg } \\
\text { et al. [6] }\end{array}$ & $\begin{array}{l}34 \\
y / F\end{array}$ & Ethmoid sinus & $\begin{array}{l}\text { Endoscopic excision, } \\
\text { ethmoidectomy }\end{array}$ & 8 mo DF & Difficulty breathing & $3 y$ \\
\hline $\begin{array}{l}\text { Mendoza } \\
\text { et al. [11] }\end{array}$ & $\begin{array}{l}1 \\
\mathrm{mo} / \mathrm{M}\end{array}$ & Ethmoid sinus & Block resection & 2 у DF & Respiratory difficulty & $1 \mathrm{mo}$ \\
\hline $\begin{array}{l}\text { Nazeer et } \\
\text { al. [12] }\end{array}$ & $\begin{array}{l}20 \\
d / M\end{array}$ & Ethmoid sinus & Surgical resection & 12 mo DF & $\begin{array}{l}\text { Respiratory difficulty } \\
\text { since birth }\end{array}$ & $20 \mathrm{~d}$ \\
\hline $\begin{array}{l}\text { Szmeja et } \\
\text { al. [13] }\end{array}$ & $8 \mathrm{y} / \mathrm{F}$ & Ethmoid sinus & Total enucleation & NA & NA & NA \\
\hline $\begin{array}{l}\text { Won et al. } \\
\text { [14] }\end{array}$ & $\begin{array}{l}28 \\
y / M\end{array}$ & Ethmoid sinus & Partial curettage & NA & $\begin{array}{l}\text { Intermittent, pulsatile } \\
\text { pain of right temporal } \\
\text { area }\end{array}$ & $\begin{array}{l}\text { Long- } \\
\text { standing }\end{array}$ \\
\hline $\begin{array}{l}\text { Cruz et al. } \\
{[15]}\end{array}$ & $\begin{array}{l}10 \\
y / F\end{array}$ & $\begin{array}{l}\text { Ethmoid sinus } \\
\text { invading orbit }\end{array}$ & $\begin{array}{l}\text { Coronal approach with en } \\
\text { bloc resection }\end{array}$ & NA & $\begin{array}{l}\text { Progressive } \\
\text { exophthalmos of left eye }\end{array}$ & $7 \mathrm{mo}$ \\
\hline $\begin{array}{l}\text { Hashimoto } \\
\text { et al. [16] }\end{array}$ & $\begin{array}{l}32 \\
y / M\end{array}$ & $\begin{array}{l}\text { Ethmoid sinus, } \\
\text { extending to frontal } \\
\text { sinus and orbit }\end{array}$ & Surgical resection & 2 у DF & $\begin{array}{l}\text { Painless left frontal } \\
\text { swelling and progressive } \\
\text { exophthalmos }\end{array}$ & $1 \mathrm{y}$ \\
\hline $\begin{array}{l}\text { Azorin et } \\
\text { al. [17] }\end{array}$ & $\begin{array}{l}46 \\
y / M\end{array}$ & Frontal sinus & $\begin{array}{l}\text { Subfrontal approach, superior } \\
\text { orbitotomy, and block } \\
\text { resection, including } \\
\text { pericranium and surrounding } \\
\text { frontal bone }\end{array}$ & $22 \mathrm{mo} \mathrm{DF}$ & $\begin{array}{l}\text { Right supraciliary frontal } \\
\text { mass }\end{array}$ & $18 \mathrm{mo}$ \\
\hline $\begin{array}{l}\text { Wolf et al. } \\
{[18]}\end{array}$ & $\begin{array}{l}35 \\
y / F\end{array}$ & $\begin{array}{l}\text { Frontal-sphenoid } \\
\text { junction with orbital } \\
\text { infiltration }\end{array}$ & $\begin{array}{l}\text { Left craniotomy with } \\
\text { piecemeal removal }\end{array}$ & NA & Frontal headache & $4 \mathrm{mo}$ \\
\hline $\begin{array}{l}\text { Perez- } \\
\text { Fernandez } \\
\text { et al. [19] }\end{array}$ & $\begin{array}{l}60 \\
y / M\end{array}$ & $\begin{array}{l}\text { Maxillary sinus with } \\
\text { extension into } \\
\text { ethmoid sinus }\end{array}$ & $\begin{array}{l}\text { Endoscopic resection and } \\
\text { post-ethmoidectomy, } \\
\text { Caldwell-Luc }\end{array}$ & 5 y DF & $\begin{array}{l}\text { Left nasal obstruction } \\
\text { with recurrent ipsilateral } \\
\text { epistaxis }\end{array}$ & $\begin{array}{l}\text { "several } \\
\text { months" }\end{array}$ \\
\hline $\begin{array}{l}\text { Koay et al. } \\
\text { [20] }\end{array}$ & $\begin{array}{l}57 \\
y / F\end{array}$ & $\begin{array}{l}\text { Nasal bone with } \\
\text { extension to frontal } \\
\text { and ethmoid sinuses }\end{array}$ & Incomplete surgical excision & NA & $\begin{array}{l}\text { Slowly expanding, } \\
\text { painless swelling over } \\
\text { bridge of nose }\end{array}$ & $2 \mathrm{y}$ \\
\hline $\begin{array}{l}\text { Baujat et } \\
\text { al. [21] }\end{array}$ & $\begin{array}{l}50 \\
y / F\end{array}$ & $\begin{array}{l}\text { Nasal bone, extension } \\
\text { into frontal and } \\
\text { ethmoidal sinuses } \\
\text { with dural involvement }\end{array}$ & $\begin{array}{l}\text { Frontal bone window with } \\
\text { dura removal }\end{array}$ & $18 \mathrm{mo} \mathrm{DF}$ & $\begin{array}{l}\text { Frontal headache, pain, } \\
\text { nasal obstruction and } \\
\text { tearing }\end{array}$ & $3 \mathrm{mo}$ \\
\hline $\begin{array}{l}\text { Wang et } \\
\text { al. [9] }\end{array}$ & $\begin{array}{l}60 \\
y / F\end{array}$ & Nasal septum & Complete surgical removal & $6 \mathrm{mo} \mathrm{DF}$ & $\begin{array}{l}\text { No clinical discomfort } \\
\text { (MH: congenital right } \\
\text { aural atresia) }\end{array}$ & $60 \mathrm{y}$ \\
\hline \multirow[t]{2}{*}{$\begin{array}{l}\text { Veras et } \\
\text { al. [22] }\end{array}$} & $\begin{array}{l}60 \\
y / F\end{array}$ & Nasal septum & Surgical excision & 12 mo DF & $\begin{array}{l}\text { Incidental } \\
\text { (asymptomatic) }\end{array}$ & NA \\
\hline & & Nasal septum & oving with & & & \\
\hline
\end{tabular}




\section{Cureus}

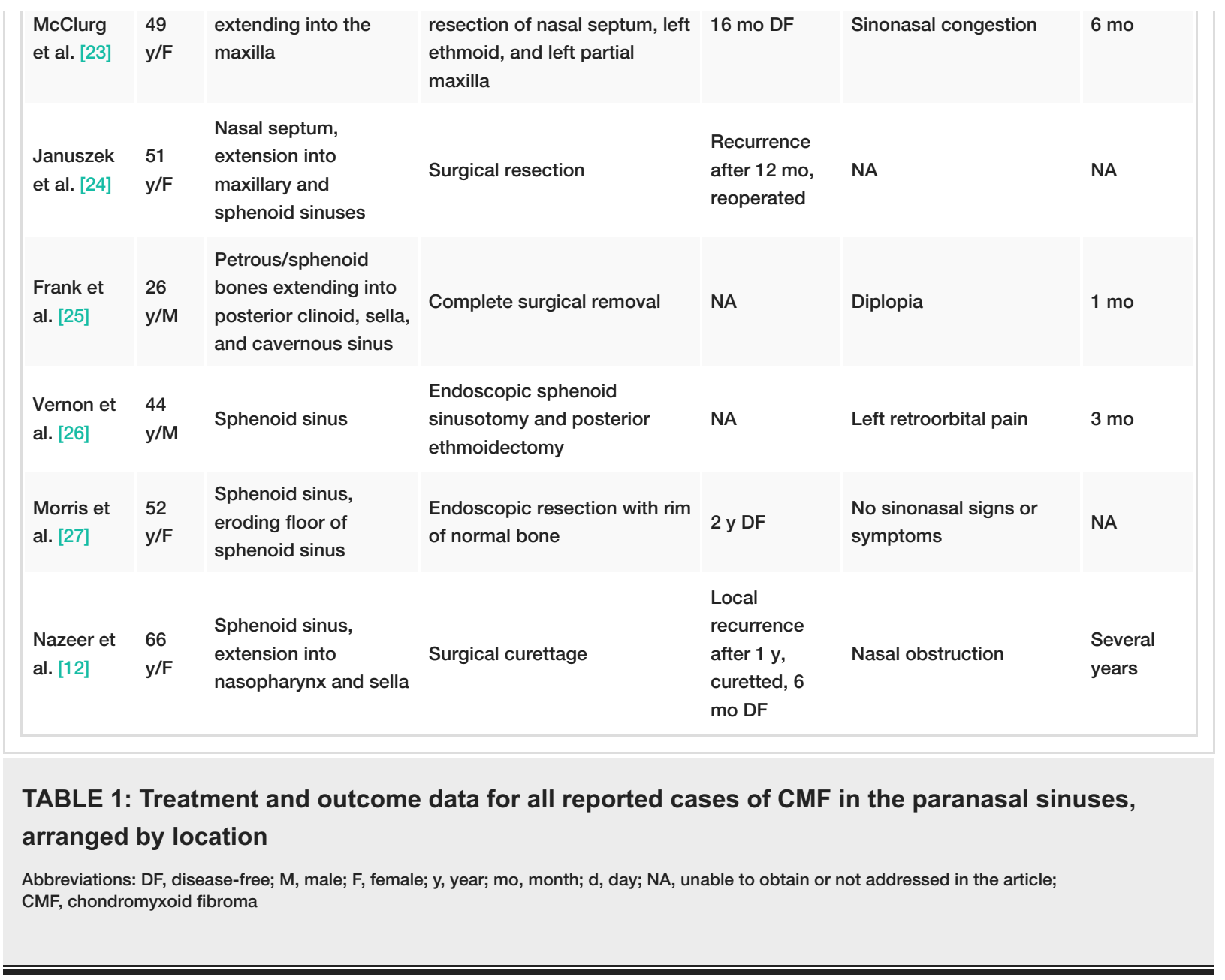

A review of the literature demonstrates inconsistent presenting symptoms. Table 1 suggests that clinical sequelae arise secondary to the mass effect rather than specific to the acute pathology of CMF. The lack of specificity of symptoms highlights the importance of a thorough examination and workup in obtaining an accurate diagnosis.

Given its rarity, an early differential would seldom, if ever, have CMF as the primary diagnosis. More common lesions, such as a chordoma or chondrosarcoma, should be considered for any lesion demonstrating calcification within a chondroid-like matrix [10]. These neoplasms portend a worse prognosis than CMF, with 10 -year survival rates of $50 \%$ for skull base chondrosarcomas and $16-32 \%$ for skull base chordomas [28].

These lesions are also difficult to differentiate radiologically. The identification of calcifications on CT should prompt the consideration of a cartilaginous or chondroid matrix-containing lesion [23]. Although some CMF lesions contain foci of calcification, these are frequently microscopic and, therefore, rarely visible on imaging [29]. Chondrosarcomas, by contrast, contain prominent, easily seen calcifications [23]. Of the 191 cases of CMF that Wu et al. studied, $87 \%$ had a purely lucent matrix while $15 \%$ had signs of mineralization [5]. MRI is the preferred radiologic modality to understand the extent of the disease process, as it provides information on soft tissue involvement. On MRI, these three lesions are all hypointense or isointense on T1 and hyperintense on $\mathrm{T} 2$, with frequent enhancement via gadolinium contrast, if used.

Given this overlap of imaging findings across various lesions, a detailed histopathologic evaluation becomes crucial in making the proper diagnosis. In their series of 36 patients with CMF, Zilmer and Dorfman reported a $22 \%$ initial misdiagnosis rate and pointed out the potential of more aggressive treatment than is required, such as amputating the affected limb for a benign lesion [30-31]. The World Health Organization defines CMF as "a benign tumor characterized by lobules of spindle-shaped or stellate cells with abundant myxoid or chondroid intercellular material separated by zones of more cellular tissue rich in spindle-shaped or round cells with a varying number of multinucleated giant cells of different sizes" [32]. Stellate or spindleshaped cells have centrally located nuclei with finely dispersed or homogeneous dark chromatin and eosinophilic cytoplasm. Nuclear pleomorphism and atypia are uncommon in CMF and are more defining of chondrosarcoma $[15,31,33]$. Additionally, the intersecting bands of myxochondroid tissue are not found in chondrosarcoma. According to Castle et al., diagnostic features of chondrosarcomas also include a "bubbly appearance to the stroma along with degenerative and liquefactive changes" [31]. Chordomas, in contrast, have the characteristic physaliferous cells (those with abundant, bubbly, or vacuolated eosinophilic 
cytoplasm), which are nearly pathognomonic for the lesion [27].

Although the standard of treatment for CMF is surgical excision, the cosmetic and functional consequences of extensive resection of craniofacial lesions have led many authors to recommend curettage specifically for facial CMF with close follow-up. Baujat et al. asserted that long-term control is best achieved via wide surgical resection by demonstrating the high recurrence rate achieved after curettage [21]. Select cases, such as the one described above, may be amenable to endoscopic resection.

Another reason to favor surgery involves the risk of residual tissue undergoing malignant transformation. Although the transformation rate is low [34], cases of malignant transformation have been reported, with an increased risk noted after radiation therapy $[4,30,35]$. A location at or near the skull base, however, imposes additional difficulty in obtaining complete resection [10]. As such, some authors have suggested postoperative irradiation as an attempt to reduce recurrence [36].

\section{Conclusions}

A review of the literature demonstrates that although an exceedingly rare tumor, representing $<0.5 \%$ of all bone tumors, CMF has been reported to occur in the sinonasal cavity. Although CMF may appear similar to chondrosarcoma and chordoma on imaging, proper treatment depends on histopathologic differentiation. A biopsy will reveal stellate cells within an abundance of a myxoid or chondroid matrix. Although curettage may be necessary in the case of inaccessible tumors, complete surgical resection is preferred to minimize the risk of recurrence.

\section{Additional Information}

\section{Disclosures}

Conflicts of interest: In compliance with the ICMJE uniform disclosure form, all authors declare the following: Payment/services info: All authors have declared that no financial support was received from any organization for the submitted work. Financial relationships: All authors have declared that they have no financial relationships at present or within the previous three years with any organizations that might have an interest in the submitted work. Other relationships: All authors have declared that there are no other relationships or activities that could appear to have influenced the submitted work.

\section{References}

1. Jaffe HL, Lichtenstein L: Chondromyxoid fibroma of bone: distinctive benign tumor likely to be mistaken especially for chondrosarcoma. Arch Pathol. 1948, 45:541-551.

2. Chondromyxoid fibroma. Dahlin's Bone Tumors. Unni KK, Inwards CY (ed): Wolters Kluwer, Philadelphia, US; 2010. 6:50-59.

3. Dahlin DC: Chondromyxoid fibroma of bone, with emphasis on its morphological relationship to benign chondroblastoma. Cancer. 1956, 9:195-203. 10.1002/1097-0142(195601/02)9:1<195::aidcncr2820090121>3.0.c0;2-c

4. Rahimi A, Beabout JW, Ivins JC, Dahlin DC: Chondromyxoid fibroma: a clinicopathologic study of 76 cases . Cancer. 1972, 30:726-736. 10.1002/1097-0142(197209)30:3<726::aid-cncr2820300321>3.0.co;2-t

5. Wu CT, Inwards CY, O'Laughlin S, Rock MG, Beabout JW, Unni KK: Chondromyxoid fibroma of bone: a clinicopathologic review of 278 cases. Hum Pathol. 1998, 29:438-446. 10.1016/s0046-8177(98)90058-2

6. Isenberg SF: Endoscopic removal of chondromyxoid fibroma of the ethmoid sinus . Am J Otolaryngol. 1995, 16:205-208. 10.1016/0196-0709(95)90105-1

7. Hakan T, Vardar Aker F: Chonromyxoid fibroma of frontal bone: a case report and review of the literature [Article in Turkish]. Turk Neurosurg. 2008, 18:249-253.

8. Lingen MW, Solt DB, Polverini PJ: Unusual presentation of a chondromyxoid fibroma of the mandible. Report of a case and review of the literature. Oral Surg Oral Med Oral Pathol. 75, 615-621. 10.1016/00304220(93)90236-w

9. Wang C, Morrow T, Friedman P, Lara JF: Condromyxoid fibroma of the nasal septum: a case report emphasizing clinical correlation. Am J Rhinol. 2000, 14:45-49. 10.2500/105065800781602885

10. Keel SB, Bhan AK, Liebsch NJ, Rosenberg AE: Chondromyxoid fibroma of the skull base: a tumor which may be confused with chordoma and chondrosarcoma: a report of three cases and review of the literature. Am J Surg Pathol. 1997, 21:577-582.

11. Mendoza M, Gonzalez I, Aperribay M, Hermosa JR, Nogues A: Congenital chondromyxoid fibroma of the ethmoid: case report. Pediatr Radiol. 1998, 28:339-341. 10.1007/s002470050369

12. Nazeer T, Ro JY, Varma DG, de la Hermosa JR, Ayala AG: Chondromyxoid fibroma of paranasal sinuses: report of two cases presenting with nasal obstruction. Skeletal Radiol. 1996, 25:779-782. $10.1007 /$ s002560050179

13. Szmeja Z, Obrebowski A, Strzyzowski M, Lukaszewski B: Chondromyxofibroma ossificans of the ethmoidal labyrinth in a child. Int J Pediatr Otorhinolaryngol. 1981, 3:151-156. 10.1016/0165-5876(81)90031-8

14. Won KY, Lee J, Kim YW, Kim EJ, Kim SW, Park YK: Chondromyxoid fibroma of the ethmoid sinus complicated by a brain abscess: a case report and literature review. Korean J Pathol. 2010, 44:547-550. 10.4132/KoreanJPathol.2010.44.5.547

15. Cruz AA, Mesquita IM, Becker AN, Chahud F: Orbital invasion by chondromyxoid fibroma of the ethmoid sinus. Ophthal Plast Reconstr Surg. 2007, 23:427-428. 10.1097/IOP.0b013e318146986c

16. Hashimoto M, Izumi J, Sakuma I, Iwama T, Watarai J: Chondromyxoid fibroma of the ethmoid sinus . 
Neuroradiology. 1998, 40:577-579. 10.1007/s002340050647

17. Azorin D, Gil A, Sanchez-Aniceto G, Ballestin C, Martinez-Tello FJ: Chondromyxoid fibroma of the frontal sinus. Br J Oral Maxillofac Surg. 2003, 41:418-420. 10.1016/S0266-4356(03)00168-2

18. Wolf DA, Chaljub G, Maggio W, Gelman BB: Intracranial chondromyxoid fibroma. Report of a case and review of the literature. Arch Pathol Lab Med. 1997, 121:626-630.

19. Perez-Fernandez CA, Armengot-Carceller M, Lozano de Arnilla CG, Valles AP, Basterra-Alegria J: Chondromyxoid fibroma of left maxillary and ethmoid sinuses [Article in Spanish] . Acta Otorrinolaringol Esp. 2009, 60:70-72. 10.1016/S2173-5735(09)70102-4

20. Koay CB, Freeland AP, Athanasou NA: Chondromyxoid fibroma of the nasal bone with extension in the frontal and ethmoid sinuses. J Laryngol Otol. 1995, 109:258-261. 10.1017/S002221510012986X

21. Baujat B, Attal P, Racy E, Quillard J, Parker F, Evennou A, Bobin S: Chondromyxoid fibroma of the nasal bone with extension into the frontal and ethmoidal sinuses: report of one case and a review of the literature. Am J Otolaryngol. 2001, 22:150-153. 10.1053/ajot.2001.22582

22. Veras EFT, Santamaria IB, Luna MA: Sinonasal chondromyxoid fibroma. Ann Diagn Pathol. 2009, 13:41-46. 10.1016/j.anndiagpath.2007.05.006

23. McClurg SW, Leon M, Teknos TN, Iwenofu OH: Chondromyxoid fibroma of the nasal septum: case report and review of literature. Head Neck. 2013, 35:1-5. 10.1002/hed.21760

24. Januszek G, Niemczyk K, Gornicka B, Gotlib T: Chondromyxoid fibroma of the nasal septum. Otolaryngol Pol. 2010, 64:88-92. 10.1016/S0030-6657(10)70041-X

25. Frank E, Deruaz JP, de Tribolet N: Chondromyxoid fibroma of the petrous-sphenoid junction. Surg Neurol. 1987, 27:182-186. 10.1016/0090-3019(87)90293-X

26. Vernon SE, Casiano RR: Sphenoid sinus chondromyxoid fibroma mimicking a mucocele. Am J Otolaryngol. 2006, 27:406-408. 10.1016/j.amjoto.2006.01.004

27. Morris LGT, Rihani J, Lebowitz RA, Wang BY: Chondromyxoid fibroma of sphenoid sinus with unusual calcifications: case report with literature review. Head Neck Pathol. 2009, 3:169-173. 10.1007/s12105-0090121-6

28. Wasserman JK, Gravel D, Purgina B: Chordoma of the head and neck: a review . Head Neck Pathol. 2018, 12:261-268. 10.1007/s12105-017-0860-8

29. Wilson AJ, Kyriakos M, Ackerman LV: Chondromyxoid fibroma: radiographic appearance in 38 cases and in a review of the literature. Radiology. 1991, 179:513-518. 10.1148/radiology.179.2.2014302

30. Zillmer DA, Dorfman HD: Chondromyxoid fibroma of bone: thirty six cases with clinicopathologic correlation. Hum Path. 1989, 20:952-964. 10.1016/0046-8177(89)90267-0

31. Castle JT, Kernig ML: Chondromyxoid fibroma of the ethmoid sinus . Head Neck Pathol. 2011, 5:261-264. 10.1007/s12105-011-0275-x

32. Pathology and Genetics of Tumors of Soft Tissue and Bone . Fletcher CD, Unni KK, Mertens F (ed): IARC Press, Lyon; 2002

33. Ghanem N, Uhl M, Altehoefer C, Adler CP: Chondromyxoid fibroma of the sinonasal cavity. Eur J Radiol Extra. 2003, 46:21-25. 10.1016/S1571-4675(03)00037-3

34. Patino-Cordoba JI, Turner J, McCarthy SW, Fagan P: Chondromyxoid fibroma of the skull base. Otolaryngol Head Neck Surg. 1998, 118:415-418. 10.1016/S0194-59989870329-8

35. Otto BA, Jacob A, Klein MJ, Welling DB: Chondromyxoid fibroma of the temporal bone: case report and review of the literature. Ann Otol Rhinol Laryngol. 2007, 116:922-927. 10.1177/000348940711601209

36. Feuvret L, Noel G, Calugaru V, Terrier P, Habrand JL: Chondromyxoid fibroma of the skull base: differential diagnosis and radiotherapy: two case reports and a review of the literature. Acta Oncol. 2005, 44:545-553. $10.1080 / 00365590500237846$ 